\title{
Non-union worker representation, foreign owners, and the performance of establishments
}

\author{
By Uwe Jirjahn* and Steffen Mueller ${ }^{\dagger}$ \\ ${ }^{\star}$ Universität Trier, Fachbereich IV, Lehrstuhl für Arbeitsmarktökonomik, \\ Universitätsring 15, 54286 Trier, Germany; e-mail: jirjahn@uni-trier.de \\ ${ }^{\dagger}$ Friedrich-Alexander-Universität Erlangen-Nürnberg, Rechts- und \\ Wirtschaftswissenschaftliche Fakultät and CESifo
}

\begin{abstract}
Using German establishment data, this study provides the first econometric analysis on the interaction of establishment-level codetermination and foreign owners. Works councils are associated with higher productivity in domestic-owned establishments while they are associated with lower productivity in foreign-owned establishments. Our results conform to the notion that foreign ownership can involve strong tensions with the institutional patterns of the host country.
\end{abstract}

JEL classifications: J53, J54, M54.

\section{Introduction}

Recent decades have witnessed an enormous growth in foreign direct investment (FDI) around the world (UNCTAD, 2004). The growth in corporate globalization has stimulated public and academic interest in the consequences for the national industrial relations systems. Yet, there is surprisingly little systematic evidence on how the functioning of a country's industrial relations system is affected by FDI. This paper provides an econometric analysis for Germany. It examines the interaction effect of foreign ownership and works councils on productivity. This examination reflects our broad interest in the extent to which foreign multinational firms adapt to local institutions or weaken the functioning of those institutions. ${ }^{1}$

Examining the interaction effect of foreign ownership with works councils is particularly interesting. Works councils have attracted considerable attention as an alternative form of worker representation to improve both the quality of

\footnotetext{
${ }^{1} \mathrm{~A}$ handful of econometric studies examine the influence of national industrial relations institutions on the inflow of FDI (Cooke, 1997; Bognanno et al., 2005; Hamm and Kleiner, 2007). Other studies investigate the effect of FDI on domestic unionization (Cooke, 2001; Dreher and Gaston, 2007; Slaughter, 2007) and the desire of workers for works councils (Addison et al., 2003; Schmitt, 2003). None of those studies examines the interaction of foreign ownership and domestic industrial relations on economic performance.
} 
working life and economic performance. They play an important role in corporate governance in many West European countries. Specifically German works councils have acquired extensive powers compared to councils in other countries. Those powers have even been strengthened by the 2001 amendment of the Works Constitution Act (WCA), the law that governs the works council system. Works councils play also a role outside Europe. In Korea, mandated councils deal with productivity concerns, training, and health and safety issues (Kleiner and Lee, 1997). In Canada, mandatory health and safety committees have been introduced in several provinces. Further, committees must be set up in case of layoffs. The committees are similar to European works councils (Adams, 1985). In the US, the interest in nonunion representation has been spurred by a sharp decline in union density and the growth of a 'representation gap' (Freeman and Rogers, 1999). Much of the political discussion has centred on the idea of mandating German-style works councils.

Economists have also shown strong interest in works councils as an institution that fosters workers' cooperation and effort through its information sharing and contract enforcement role (Freeman and Lazear, 1995). This is documented by a remarkably increasing number of econometric studies on the consequences of German works councils. Recent examinations typically obtain neutral or positive effects on training, employee retention, productivity, innovation, family friendly practices, and the use of performance pay (Addison et al., 2001; Heywood and Jirjahn, 2002, 2009; Frick and Moeller, 2003; Huebler and Jirjahn, 2003; Askildsen et al., 2006; Smith, 2006; Jirjahn and Kraft, 2007, 2011; Wagner, 2008; Pfeifer, 2011; Mueller, 2012). Yet, sociological case studies indicate that councils do not automatically live up to their potential (Frege, 2002). The functioning of works councils depends on the managerial environment. In what follows we examine the moderating role of foreign ownership in the relationship between works councils and establishment performance.

From a theoretical viewpoint, the interaction of works councils and foreign owners is ambiguous. On the one hand, it may be positive. In foreign-owned establishments, there exists a high level of uncertainty and ambiguity from the workers' perspective. Works councils ensuring that foreign owners behave in accordance with their implicit and explicit obligations reduce this uncertainty and, hence, foster workers' effort and cooperativeness. On the other hand, there may be a negative interaction. While the works council of the local establishment has no access to the information possessed by the parent company's managers, the managers of the foreign parent company lack sufficient information about local conditions of the subsidiary. The result is a lot of time spent in meetings and adversarial bargaining to find local solutions. Moreover, the council's power to protect employees' interests is weaker as foreign owners can more easily threaten to transfer production abroad. Finally, foreign owners may have a stronger shareholder value orientation implying a shorter time horizon and, hence, a lower interest in a cooperative relationship with the works council. 
Our empirical examination is based on a large representative data set from the IAB Establishment Panel. Random effects estimates provide evidence of a strong negative interaction of foreign ownership and works councils. This interaction effect implies that works councils play completely different roles in domesticand foreign-owned establishments. While previous studies often found a positive association between works council incidence and productivity, our results show that this only holds true for domestic-owned but not for foreign-owned establishments. The incidence of a council is negatively associated with productivity in foreign-owned establishments. This finding suggests that foreign ownership undermines the functioning of establishment-level codetermination in Germany. It conforms to the general notion that foreign ownership can involve strong tensions with the institutional patterns of the host country.

Our pattern of results is robust with respect to alternative productivity measures (value added per employee vs sales per employee). The pattern of results also remains when restricting the estimation sample to medium sized establishments. Moreover, it persists in exploratory treatment effects estimates accounting for the possible endogeneity of works council incidence.

The rest of the paper is organized as follows. In Section 2, the institutional framework is described. Section 3 presents our background discussion. Section 4 describes data and variables. The estimates are presented in Section 5. Section 6 concludes.

\section{Institutional framework}

German industrial relations are characterized by a dual structure of employee representation. While unions negotiate over wage rates and general aspects of the employment contracts, works councils provide a highly developed mechanism for establishment-level participation. Collective contracts are typically negotiated between unions and employers' associations on a sectoral level. Employers are covered by industry-level agreements if they are members of employers' associations. The share of employers covered by firm-level agreements is very small.

Works councils are formally independent of collective bargaining. Their rights are defined in the WCA. Workers in establishments with five or more employees may elect council members but the creation of the council depends on the initiative of the establishment's employees. In fact, councils are not present in the majority of eligible establishments. Councils negotiate over a bundle of interrelated establishment policies. On some issues they have the right to information and consultation, on others a veto power over management initiatives and on still others the right to coequal participation in the design and implementation of policy. Their rights are strongest in social and personnel matters such as the introduction of new payment methods, the introduction of technical devices designed to monitor worker performance, and up and down grading. They also have consultation rights, though not as strong, in matters such as changes in equipment and working methods that affect job requirements, decisions relating to manpower planning and planned 
structural alterations to the plant. Their participation rights in financial matters cover only information provision.

Works councils have functions that are distinct from those of unions. They do not have the right to strike. If council and management fail to reach an agreement, they may appeal to an internal arbitration board or to the labour court. Moreover, the WCA does not allow wage negotiations. The aim is to restrict adversarial bargaining on the establishment level. Rather works councils are designed to increase joint establishment surplus. Council representatives are required by law to cooperate with management 'in a spirit of mutual trust... for the good of the employees and of the establishment'.

\section{Background discussion}

\subsection{Economic effects of works councils}

The existence of information asymmetries and commitment problems is one explanation as to why work councils may play the intended role in fostering cooperative and trustful industrial relations. Employees will withhold effort and cooperation when an employer cannot credibly commit to take into account their interests. There is a variety of situations in which commitment problems can arise. For example, information asymmetries may cause workers to refuse concessions even when concessions are necessary to ensure competitiveness of the establishment. If employees do not share the same economic information possessed by management, they may fear that the employer overstates a crisis to demand greater concessions. Similarly, workers fearing job loss due to organizational change may try to sabotage a management-initiated restructuring of production. Moreover, if information about potentially performance-enhancing innovations is in the hands of the employees, they may not wish to reveal it for the fear that the employer may use the information to their disadvantage.

Worker representation is one way to protect the interests of the workforce and to foster workers' effort and cooperation resulting in mutual gains for the employees and the owners of the establishment (Smith, 1991; Freeman and Lazear, 1995). Providing works councils with information rights helps reduce information asymmetries. This makes it easier to verify employers' claims. Moreover, providing works councils with veto and coequal participation rights helps avoid that employers unilaterally take actions without considering workers' interests. The councils' role in building trustful employer-employee relations is also strengthened by the legal requirement to cooperate with management. Altogether, the unique institutional design suggests that councils have the potential to increase establishment performance by solving commitment problems.

However, from a theoretical viewpoint, there are opposing effects making the relationship between works councils and establishment performance ambiguous. Codetermination requires meetings between works councillors and managers. The increased time spent in discussions may slow down decision making and, hence, may result in delayed decisions. Moreover, even though the WCA aims at 
restricting distributional conflicts, codetermination de facto may aggravate conflicts within the establishment. One possibility is that works councils use their codetermination rights not for increasing joint establishment surplus but rather for rent-seeking activities (Addison et al., 2001). A council may use its codetermination rights on social or personnel matters to obtain employer concessions even on issues where it has no legal powers. The council may negotiate higher wages and less productive work practices that require lower effort by the workers. A second possible scenario is that rent-seeking owners or managers are not interested in long-term cooperation with the workforce (Jirjahn, 2003a; Jirjahn and Smith, 2006). They may rather prefer to maximize short-term profitability by reneging on implicit contracts with the employees. In this case management may spend resources in weakening the works council instead of investing those resources in performance-enhancing projects. The council may try to act as a countervailing power in order to protect employee interests. However, the likely outcome is a lot of time spent in adversarial bargaining.

Altogether, this line of reasoning suggests that the functioning of establishmentlevel codetermination depends on cooperative relationships between works council and management. Indeed sociological case studies reveal a wide range of industrial relations regimes characterized by different interactions of management and works councils (Frege, 2002). Most of the econometric studies on the performance effects of works councils have ignored these interactions. Specifically, interactions of works councils and foreign owners have been neglected.

\subsection{The interaction with foreign owners}

A crucial aspect of the managerial environment is whether the establishment is in the hands of domestic or foreign owners. The existence of multinational enterprises is often explained by their superior products or production processes to which other firms have no access (Markusen, 1995). Specifically, knowledge-based assets embodied in the human capital of the employees, patents or other exclusive technical knowledge, copyrights or trademarks, or even more intangible assets such as management practices, know-how, or the reputation of the firm give rise to foreign direct investment. These firm-specific assets can be transferred relatively easy back and forth across space. Moreover, like a public good within the firm, they can be supplied to additional production facilities at very low costs. However, even if multinational enterprises have superior firm-specific assets, this does not necessarily mean that foreign direct investment is always efficient. Multinational enterprises may use their superior assets for rent-seeking activities and exploitation of market power (Bellak, 2004).

The basic point for our analysis is that the personnel policy of foreign-owned firms differs (to a greater or lesser extent) from that of domestic-owned firms (Doeringer et al., 1998; Walsh, 2001; Poutsma et al., 2006; Freeman et al., 2008; Bloom and Van Reenen, 2010). Even rent sharing across borders appears to play a role within multinational enterprises (Budd and Slaughter, 2004). While this 
reflects the desire to use organizational capabilities worldwide as a source of competitive advantage, the personnel policy of foreign owners may involve tensions with the cultural and institutional context of the host country (Kostova and Roth, 2002). This brings us to the question whether there is an interaction effect between foreign owners and works councils in Germany.

From a theoretical viewpoint the sign of the interaction effect is ambiguous. Agell (1999) has argued that employee representation is particularly important in order to insure workers against the high risks associated with international trade. A related reasoning might hold true for foreign ownership. If the local establishment adopts practices from its foreign parent company, there is a high level of uncertainty and ambiguity from the workers' perspective. This in turn may result in resistance to change. Change requires renewed effort. Moreover, workers may fear that they will lose their jobs due to competence-destroying change. A works council may ensure that the foreign parent company behaves in accordance with its implicit and explicit commitments and that it does not take excessive advantage of the local establishment. Hence, the council may help to build the trust necessary for a successful adoption of the parent company's practices. This suggests a positive interaction of codetermination and foreign ownership.

However, as indicated by case studies (Mueller, 1998; Royle, 1998; Raess and Burgoon, 2006), there may be opposing effects resulting in a negative interaction. First, important decisions are made by managers of the foreign parent company and not by managers of the local establishment. As the council of the local establishment has only very limited access to the information possessed by the parent company's managers, it is less effective in reducing information asymmetries and building trust. Quite the contrary, the council is more likely to resist change if it has no access to relevant information and, hence, distrusts foreign owners. Lack of transparency implies that it is more difficult for local managers to convince the council. The result is a lot of time spent in meetings and adversarial bargaining. In this situation, a council may rather hinder an effective reorganization. Moreover, even if local managers and works council find a solution, local managers have to convince the head office. If managers of the foreign parent company lack sufficient information about local conditions of the subsidiary, they are less likely to agree. This may be also the case if the parent company's managers have little experience with codetermination. In this sense, the intervention of an uninformed or inexperienced third party complicates negotiations between local managers and works councils and, hence, results in delayed decisions.

Second, evidence from Britain suggests that strong worker organizations are more likely to play a productive voice role (Fernie and Metcalf, 1995; Bryson, 2004). This may also hold true for Germany. Only a strong works council may be able to protect workers against employer opportunism and, hence, to foster trust and cooperation. Yet, foreign ownership is very likely to weaken the bargaining strength of worker organizations. If the foreign owner maintains capacity to produce the same good in different national markets, the foreign owner can more easily threaten to transfer production abroad (Caves, 1996; Fabbri et al., 2003; 
Slaughter 2007). ${ }^{2}$ As a consequence of lower bargaining power, the works council is less effective in punishing employer opportunism. This in turn increases the employer's incentive to renege on promises made to the workforce. While employer opportunism may increase short-term profitability, it destroys trust and cooperation and, hence, harms productivity. Moreover, if the works council cannot effectively protect employees against employer opportunism, it may use its remaining bargaining power to specialize in rent seeking activities (Gaston, 2002).

Third, the 'varieties of capitalism' approach suggests that patient capital and codetermination are complementary institutions contributing to increased firm performance (Hall and Soskice, 2001). According to this view, codetermination requires patient capital to cooperatively realize long-term mutual gains for investors and employees. Yet, foreign owners are often thought to have a stronger focus on shareholder value (Jackson et al., 2005). This may particularly hold true for Germany that experienced a rise in the number of Anglo-American investors. To the extent shareholder value orientation is associated with a shorter time horizon of investors, management is less interested in building long-term cooperation. ${ }^{3}$ If managers prefer short-term profitability over long-term growth, they will spend time and effort in isolating and weakening the council. This in turn is very likely to decrease productivity.

\section{Data and variables}

We draw data from the IAB Establishment Panel. This is a representative sample of establishments (with at least one employee covered by social insurance) from all sectors in the German economy. Infratest Sozialforschung, a professional survey and opinion research institute, conducts the interviews. The data are collected on the basis of a questionnaire and personal interviews with the owner or top manager of the establishment. Each year since 1993 (1996), the IAB Establishment Panel has surveyed several thousand establishments in Western (Eastern) Germany. Basic information on the establishment and a core set of questions are asked annually. Additional topics are sampled in successive waves.

In the year 2000 the sample was substantially increased. As the WCA has been reformed in 2001, we use waves 2001 to 2007 for our analysis. The dependent

\footnotetext{
${ }^{2}$ Indeed, several empirical studies confirm that multinational enterprises are (to a greater or lesser extent) footloose. Using Irish data, Goerg and Strobl (2003) show that multinational enterprises are more likely to close local plants. Bernard and Sjoeholm (2003) obtain a similar result for Indonesia. Girma and Goerg (2004) find for the UK that foreign owned firms have higher levels of outsourcing. Relatedly, Scheve and Slaughter (2004) show for the UK that foreign ownership is associated with individual perceptions of economic insecurity. Andrews et al. (2007) confirm for Germany that foreign ownership is associated with increased job insecurity. Finally, Navaretti et al. (2003) use data from 11 European countries to show that employment adjustment in foreign-owned firms is faster than in domestic-owned firms. Moreover, foreign-owned firms appear to be able to bypass national labour market regulations.

${ }^{3}$ The extreme case is the breach of trust in hostile takeovers (Shleifer and Summers, 1988). Indeed, barriers to hostile takeovers seem to have eroded in Germany (Jackson et al., 2005).
} 
variable is log of productivity, with productivity being defined as value added (sales-material costs) per employee. Each wave of interviews provides retrospective information on productivity in the previous year. In order to regress productivity on establishment characteristics of the same year, this information is related to explanatory variables provided by the previous wave. Hence, we examine the determinants of establishment performance for the years 2001 to 2006 . We exclude nonprofit organizations, the public sector, mining, construction, fishing, and agriculture, hunting, and forestry. Furthermore, banking and insurance are excluded because of different output measures. Finally, as the WCA only applies to establishments with at least five employees, the analysis is restricted to establishments that meet this minimum size. After eliminating observations for which full information is not available, the sample size is 20,276. Table 1 shows definitions and descriptive statistics.

Our first key explanatory variable is a dummy for the presence of a council. Second, we include a dummy for the presence of a dominant foreign owner. The reference category comprises establishments with dominant domestic ownership. ${ }^{4}$ As the interaction effect of works council incidence and foreign ownership plays a key role in our analysis we also take into account an interaction term of both indicator variables.

The survey allows including a rich set of further explanatory variables. We control for capital intensity, broad industry affiliation, year of observation, location in East Germany, single-establishment status, vintage of production technology, personnel turnover, usual weekly hours, employer-provided further training, and workforce composition. ${ }^{5}$ Specifically controlling for workforce composition appears to be important as Doucouliagos and Laroche (2003) have shown that the estimated effect of worker representation can crucially depend on those controls. Thus, variables for the proportions of women, part-time employees, skilled employees, and apprentices are included.

Furthermore, dummy variables for collective bargaining coverage take into account that works councils are part of a broader industrial relations system that involves worker representation through unions. Collective bargaining is divided into bargaining at the industry and at the firm level. Specifically, collective bargaining at the industry level has been thought to impose restrictions on the establishments' flexibility (Lindbeck and Snower, 2001). Those restrictions may harm productivity.

However, collective bargaining coverage may also have an important indirect effect as it can moderate the relationship between establishment-level codetermination and establishment performance. Building on Freeman and Lazear (1995), Huebler and Jirjahn (2003) argue that collective bargaining

\footnotetext{
${ }^{4}$ We exclude establishments with dispersed ownership or with dominant public owners from the analysis.

${ }^{5}$ The survey contains information on investment. This information can be used to calculate the capital stock (Mueller, 2008).
} 


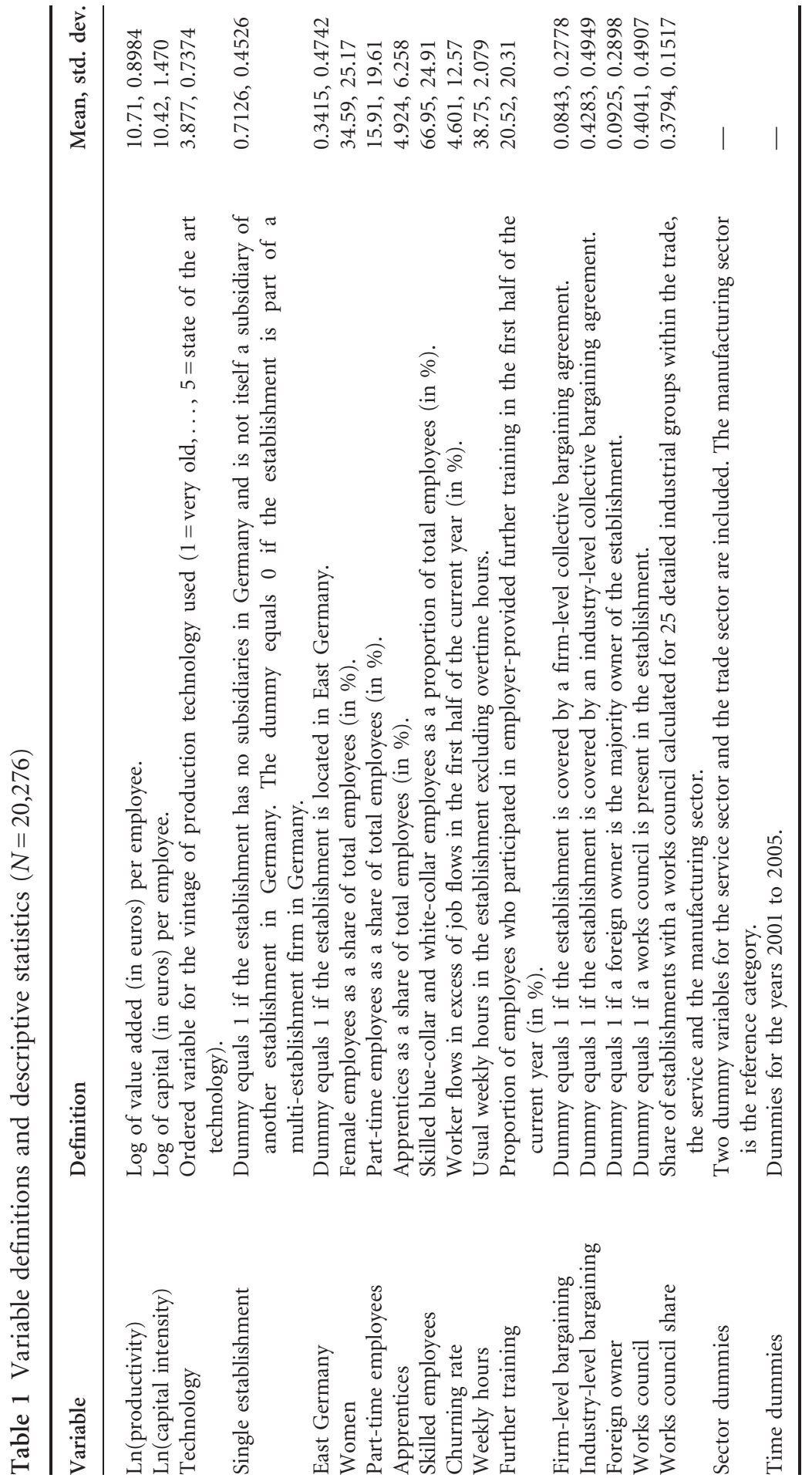


coverage reduces distributional conflicts within establishments, allowing councils to play a more productive role and engage in less rent seeking. Huebler and Jirjahn's empirical analysis provides supporting evidence. They find a positive interaction effect of works councils and collective bargaining coverage on productivity. This positive interaction effect is confirmed by several other studies (Jirjahn, 2003b; Wagner et al., 2006; Renaud, 2008; Wagner, 2008). ${ }^{6}$ Against this background, we include interaction terms of industry-level and firm-level collective bargaining coverage with works council incidence.

\section{Empirical analysis}

\subsection{Basic estimates}

Our basic regressions are based on a random effects model. The model is estimated by generalized least squares. Let $\ln \left(Y_{i t}\right)$ be the log of establishment $i$ 's $(i=1, \ldots, N)$ productivity in year $t(t=2001, \ldots, 2006)$. The random effects model is given by

$$
\ln \left(Y_{i t}\right)=\alpha^{\prime} x_{i t}+\varepsilon_{i t}+u_{i},
$$

where $x_{i t}$ is the vector of establishment characteristics, $\alpha$ the vector of coefficients, $\varepsilon_{i t}$ the time-varying error term, and $u_{i}$ the random error component that is associated with each establishment but invariant over time. The random effects model has the advantage that it allows including time-invariant or nearly time-invariant explanatory variables in the regression. A potential limitation may be the requirement that the random effects are uncorrelated with the other regressors. The inclusion of a rich set of establishment controls should mitigate this limitation. Nonetheless we will discuss alternative estimation methods later on.

Table 2 presents the random effects regression results on the determinants of productivity. Many of the control variables take statistically significant coefficients of the expected sign. Capital intensity, technology, employer-provided further training, and the share of skilled employees are positive determinants. Personnel turnover, weekly hours, and the shares of women, part-time employees and apprentices play a negative role. Furthermore, East German establishments and single establishments are less productive. ${ }^{7}$

The estimation shown in column (1) does not account for interaction effects. Both the presence of foreign owners and the incidence of a works council are

\footnotetext{
${ }^{6}$ There is evidence that the interaction of works councils and collective bargaining also plays a role in other dimensions of establishment performance. Councils appear to be better able to negotiate successful performance pay arrangements and family friendly practices when the workplace is covered by collective bargaining (Heywood and Jirjahn, 2002, 2009). They have a stronger effect on reducing personnel turnover in covered establishments (Frick and Moeller, 2003; Heywood et al., 2010; Pfeifer, 2011). There is even evidence of a positive interaction effect on the profitability of establishments (Mueller, 2011).

${ }^{7}$ Note that not only domestic-owned but also foreign-owned establishments can be single establishments within Germany. A foreign-owned establishment is a single establishment if it is not part of a foreign-owned multi-establishment firm within Germany.
} 
Table 2 Determinants of productivity; all establishments

\begin{tabular}{|c|c|c|c|}
\hline Variable & $\begin{array}{l}\text { (1) } \\
\text { Method: } \\
\text { random effects }\end{array}$ & $\begin{array}{l}(2) \\
\text { Method: } \\
\text { random effects }\end{array}$ & $\begin{array}{l}\text { (3) } \\
\text { Method: } \\
\text { random effects }\end{array}$ \\
\hline Ln(capital intensity) & $0.1772(0.0057)^{\star * *}$ & $0.1772(0.0057)^{* * *}$ & $0.1765(0.0057)^{* * *}$ \\
\hline Technology & $0.0249(0.0071)^{\star \star * \star}$ & $0.0246(0.0071)^{\star * * *}$ & $0.0245(0.0071)^{\star \star \star}$ \\
\hline Single establishment & $-0.0704(0.0137)^{\star * *}$ & $-0.0692(0.0137)^{\star * *}$ & $-0.0685(0.0137)^{\star * \star}$ \\
\hline East Germany & $-0.2337(0.0353)^{\star * *}$ & $-0.2619(0.0194)^{* * *}$ & $-0.2629(0.0194)^{\star * *}$ \\
\hline Women & $-0.0014(0.0003)^{* * *}$ & $-0.0014(0.0003)^{\star * *}$ & $-0.0014(0.0003)^{\star * *}$ \\
\hline Part-time employees & $-0.0060(0.0004)^{\star * *}$ & $-0.0060(0.0004)^{\star * *}$ & $-0.0060(0.0004)^{* * *}$ \\
\hline Apprentices & $-0.0023(0.0010)^{\star *}$ & $-0.0022(0.0010)^{\star *}$ & $-0.0022(0.0010)^{\star *}$ \\
\hline Skilled employees & $0.0028(0.0002)^{* * *}$ & $0.0027(0.0002)^{\star * \star}$ & $0.0027(0.0002)^{* * *}$ \\
\hline Churning rate & $-0.0008(0.0004)^{\star *}$ & $-0.0008(0.0004)^{\star *}$ & $-0.0008(0.0004)^{\star *}$ \\
\hline Weekly hours & $-0.0208(0.0037)^{\star * *}$ & $-0.0209(0.0037)^{\star \star \star}$ & $-0.0202(0.0037)^{\star * *}$ \\
\hline Further training & $0.0030(0.0004)^{* * *}$ & $0.0030(0.0004)^{\star * *}$ & $0.0030(0.0004)^{\star * *}$ \\
\hline Firm-level bargaining & $-0.0268(0.0196)$ & $-0.0264(0.0196)$ & $0.0059(0.0290)$ \\
\hline Industry-level bargaining & $-0.0200(0.0137)$ & $-0.0183(0.0137)$ & $-0.0452(0.0163)^{\star * *}$ \\
\hline Foreign owner & $0.1418(0.0247)^{\star * *}$ & $0.3467(0.0466)^{\star * * *}$ & $0.3432(0.0466)^{\star * *}$ \\
\hline Works council & $0.1665(0.0175)^{\star * *}$ & $0.1858(0.0179)^{* * *}$ & $0.1531(0.0236)^{\star * \star}$ \\
\hline Works council $\mathrm{x}$ foreign owner & - - & $-0.2705(0.0522)^{\star \star \star}$ & $-0.2686(0.0522)^{\star * *}$ \\
\hline $\begin{array}{l}\text { Works council x firm-level } \\
\text { bargaining }\end{array}$ & - & - & $-0.0267(0.0402)$ \\
\hline $\begin{array}{l}\text { Works council } \mathrm{x} \text { industry-level } \\
\text { bargaining }\end{array}$ & - & - & $0.0731(0.0275)^{\star * \star}$ \\
\hline Constant & $9.523(0.1579)^{\star * *}$ & $9.518(0.1577)^{* * *}$ & $9.504(0.1578)^{* \star *}$ \\
\hline Sector dummies & Included & Included & Included \\
\hline Time dummies & Included & Included & Included \\
\hline Number of observations & 20,276 & 20,276 & 20,276 \\
\hline Number of establishments & 6,784 & 6,784 & 6,784 \\
\hline$R^{2}$ & 0.2792 & 0.2815 & 0.2824 \\
\hline Rho & 0.6647 & 0.6641 & 0.6638 \\
\hline
\end{tabular}

Notes: Dependent variable: $\operatorname{Ln}$ (productivity). Rho is the share of total variation of the error term coming from the time-invariant component. Standard errors are in parentheses. ${ }^{* *}$ Statistically significant at the $5 \%$ level; ${ }^{* *}$ at the $1 \%$ level.

associated with higher productivity. The estimated coefficients are not only statistically but also economically significant. The presence of a foreign owner is associated with a roughly $14 \%$ and the incidence of a works council with a roughly $17 \%$ increase in productivity. ${ }^{8}$ The question at issue is now whether foreign owners and works councils have an interaction effect.

\footnotetext{
${ }^{8}$ While recent studies on German works councils usually obtain a positive productivity effect of establishment-level codetermination, the size of the estimated coefficient differs remarkably across studies. Mueller (2012) finds that the incidence of a works council is associated with a $6 \%$ higher productivity. Frick (2002) obtains a substantially larger influence. His estimates suggest that productivity is as much as $25-30 \%$ higher in establishments with a council. An even larger productivity effect is estimated by Addison et al. (2000). For establishments with 101-1000 employees, they find that the incidence of a council is associated with an increase in productivity by 43,830 German marks (Table 6 in
} 
The regression shown in column (2) includes an interaction term of works council incidence and foreign ownership. The inclusion of the interaction variable does not change the general pattern of results but does influence the coefficients on works council incidence, a modest increase, and foreign ownership, a large increase. The interaction itself is large and negative. The critical point is that the size of the coefficient is larger than the positive coefficient on the works council variable itself. As a consequence the net coefficient is negative. Hence, our findings support the notion that managers in domestically owned establishments are able to cooperate with works councils to improve performance whereas foreign ownership involves unproductive tensions between management and works councils.

To check the robustness of our results, we additionally include interactions of the works council variable with the collective bargaining variables. As emphasized, previous research has shown that works councils play a more productive role in establishment covered by collective bargaining. Column (3) presents the estimation. The controls continue to exhibit the same general pattern, but now the negative coefficient on industry-level bargaining is significant for the first time. The negative link between industry-level bargaining and productivity may be explained by the restrictions centralized bargaining imposes on the establishments' flexibility. However, the estimation also provides evidence of a significantly positive interaction with works councils. This conforms to the hypothesis that centralized bargaining has an indirect performance-enhancing effect by reducing distributional conflicts at the establishment level and, hence, strengthening the productive role of works councils. Interestingly, the estimation provides no evidence that firm-level bargaining plays a direct or indirect role in establishment productivity.

Most importantly, the inclusion of the additional interaction terms does not change our key finding. The works council variable takes a significantly positive coefficient while the coefficient on the interaction of works councils with foreign ownership is significantly negative. The magnitude of the negative interaction coefficient remains larger than the magnitude of the positive works council coefficient. The resulting negative net effect is confirmed by a t-test. The null hypothesis that the sum of both coefficients is equal to zero is rejected at the $5 \%$ significance level. The net effect is also economically significant. In a foreign owned establishment, the presence of a works council is associated with a roughly $8 \%$ lower productivity.

Altogether, the estimates provide evidence that the functioning of establishmentlevel codetermination critically depends on the type of ownership. In domesticowned establishments, works councils appear to play the intended role in creating joint establishment surplus. This conforms to theories suggesting that works councils can increase performance by building trust and cooperation. Yet, in

their article). Compared to the mean of 134,620 German marks (Table A2 in their article), this is an increase by about $33 \%$. However, Addison et al. (2000) find no significant effect for smaller establishments. Altogether, our estimated coefficient appears to lie in the middle range of estimated productivity effects of works councils. 
foreign-owned establishments, codetermination tends to play a rather counterproductive role. As outlined in our theoretical section, there may be three reasons for this negative interaction effect. First, a high degree of opacity and the intervention of a rather inexperienced foreign parent company complicate negotiations between council and local management. Second, the potential threat of transferring production abroad reduces the council's power to protect employees against employer opportunism. As a consequence, the council is likely to use its remaining bargaining power to engage in rent seeking activities. Third, foreign owners may have a stronger focus on shareholder value. To the extent this implies a shorter time horizon, management is less interested in long-term cooperation with the works council. This in turn is likely to result in adversarial industrial relations.

\subsection{The issue of establishment size}

Works council incidence is correlated with establishment size. Very small establishments usually do not have a works council while councils are present in almost all large establishments. Hence, we check the robustness of results by excluding very small and very large establishments from the analysis. Following previous studies (Addison et al., 2001; Jirjahn, 2003a, 2003b; Wagner, 2008), we provide additional estimates for a subsample of medium sized establishments with between 21 and 100 employees.

Table 3 summarizes the results on the key variables. The estimates confirm our basic findings. In establishments with domestic owners, the presence of a works council is associated with increased productivity. However, compared to the full sample of establishments, the performance-enhancing influence of works councils appears to be smaller. In medium sized establishments with domestic owners, the presence of a works council is associated with a roughly $7 \%$ higher productivity. Moreover, the estimates with the subsample of medium sized establishments confirm that foreign ownership and works council incidence interact negatively with each other. The negative coefficient on the interaction term again dominates the positive coefficient on the works council variable so that a negative net effect results.

\subsection{Value added vs sales}

A further robustness check concerns our dependent variable. So far we have used value added per employee. Value added is defined as sales minus material costs. The variable for material costs has more missing values than the variable for sales so that we lose observations. To avoid the loss of observations one may use sales per employee as an alternative productivity measure. Thus, we reestimated all regressions using this alternative measure. Appendix Table A1 provides the results.

The estimates shown in columns (1) and (2) use all observations for which information on sales and the explanatory variables is available. As we can now 
Table 3 Determinants of productivity; establishments with 21-100 employees

\begin{tabular}{|c|c|c|c|}
\hline Variable & $\begin{array}{l}\text { (1) } \\
\text { Method: } \\
\text { random effects }\end{array}$ & $\begin{array}{l}\text { (2) } \\
\text { Method: } \\
\text { random effects }\end{array}$ & $\begin{array}{l}\text { (3) } \\
\text { Method: } \\
\text { random effects }\end{array}$ \\
\hline Firm-level bargaining & $-0.0385(0.0354)$ & $-0.0383(0.0354)$ & $0.0253(0.0482)$ \\
\hline Industry-level bargaining & $-0.0072(0.0238)$ & $-0.0063(0.0238)$ & $-0.0293(0.0280)$ \\
\hline Foreign owner & $0.3009(0.0538)^{* * *}$ & $0.4296(0.0761)^{\star \star *}$ & $0.4301(0.0761)^{\star * *}$ \\
\hline Works council & $0.0738(0.0290)^{\star *}$ & $0.0866(0.0294)^{\star \star \star}$ & $0.0706(0.0388)^{\star}$ \\
\hline Works council $\mathrm{x}$ foreign owner & - & $-0.2364(0.989)^{\star \star}$ & $-0.2386(0.0990)^{\star *}$ \\
\hline $\begin{array}{l}\text { Works council x firm-level } \\
\text { bargaining }\end{array}$ & - & - & $-0.1097(0.0712)$ \\
\hline $\begin{array}{l}\text { Works council } \mathrm{x} \text { industry-level } \\
\text { bargaining }\end{array}$ & - & - & $0.0557(0.0472)$ \\
\hline Number of observations & 5,583 & 5,583 & 5,583 \\
\hline Number of establishments & 1,934 & 1,934 & 1,934 \\
\hline$R^{2}$ & 0.2369 & 0.2382 & 0.2410 \\
\hline Rho & 0.6819 & 0.6817 & 0.6808 \\
\hline
\end{tabular}

Notes: Dependent variable: $\operatorname{Ln}$ (productivity). Rho is the share of total variation of the error term coming from the time-invariant component. Standard errors are in parentheses. ${ }^{*}$ Statistically significant at the $10 \%$ level; ${ }^{* *}$ at the $5 \%$ level; ${ }^{* *}$ at the $1 \%$ level. Note that all control variables listed in Table 2 are included in each estimation.

include observations with missing information on material costs, the sample sizes are larger than those in Tables 2 and 3. For the regressions with all establishments, we gain 1,717 additional observations. For the regressions with medium sized establishments, the sample size increases by 446 observations. Nonetheless, the pattern of key results is confirmed even when using sales per employee as productivity measure. The variables for foreign ownership and works council incidence take significantly positive coefficients while the interaction term takes a significantly negative coefficient.

However, the magnitude of the coefficients appears to be smaller when using sales per employee. This may be due to different samples or simply due to using a different productivity measure. In the regressions shown in columns (3) and (4), observations with missing information on material costs are excluded so that we have the same samples as in Tables 2 and 3. The magnitude of the coefficients continues to be smaller when using sales per employee. Hence, differences in the magnitudes of the coefficients are primarily due to using different productivity measures. The critical point is that measuring productivity by sales per employee neglects an important input factor of production, namely materials. Thus, value added per employee is our preferred productivity measure.

\subsection{The issue of endogeneity}

We recognize the possibility that our previous results may suffer from endogeneity when there are unobserved factors influencing both the incidence of a council and 
the productivity of the establishment. Recent studies indicate that works councils are more likely to be adopted in establishments facing a poor economic situation (Jirjahn, 2009, 2010; Mohrenweiser et al., 2012; Mueller, 2012). In such situation, councils may help workers protect the quasi rents they have created by their efforts or human capital investments. Hence, if the economic situation is not fully accounted for, the performance-enhancing effect of works councils is underestimated as the coefficient on the works council variable partially reflects poor economic conditions. Different approaches have been used in the works council literature to address the issue of endogeneity. Each approach has its specific limitations so that attempts to account for the potential endogeneity of works councils have a rather exploratory character.

One approach is to compare the productivity growth of establishments introducing a works council with the productivity growth of establishments that continue to operate without a council (Addison et al., 2004). Propensity score matching may be used to find establishments for both groups that share similar observable characteristics. A related approach is to run fixed effects regressions (Addison et al., 2006). The fixed effects model only relies on within establishment variation of the explanatory variables. Thus, in that model, the coefficient on the works council variable is identified only by establishments with a change in works council status.

Both approaches entail three problems. First, there are relatively few observations with a change in the works council status. In our sample, there are 416 status changes. That is $2 \%$ of all observations. ${ }^{9}$ Small within variation can result in highly inefficient estimates. Even more problematically, 93 establishments report that their works council status has changed more than one time (e.g., first the introduction of a council and thereafter the abolishment). This accounts for 202 changes and, hence, for almost half of all observed changes in works council status. On the one hand, this may reflect measurement error. On the other hand, it may reflect trial-and-error experimentation with highly unclear productivity effects. This brings us to the second problem. Jirjahn et al.(2011) show that works councils need time to live up to their potential as organizational learning plays an important role in the functioning of codetermination. Their estimates suggest that the performance-enhancing effect of a newly created council is weak. However, the effect increases for a long time reaching a peak after more than 30 years. Given that our sample covers a relatively short period of six years, focusing on the introduction of works councils implies that short-term and rather insignificant effects

\footnotetext{
${ }^{9}$ The number of changes in ownership status (from foreign owned to domestically owned or vice versa) is with less than $1 \%$ of all observations even smaller. Hence, it would be difficult to account for potential endogeneity of ownership status by comparing establishments with and without a change in ownership status. Such approach is used by Andrews et al. (2009) and Hijzen et al. (2010) to examine the wage effects of foreign ownership. The problem of a small number of changes in ownership status might be less severe in their studies as they consider individual workers' wages. Even if there is only a small number of establishments with a change in ownership status, a large number of employees may be affected.
} 
are estimated. These effects cannot be generalized to the entire population of works councils. Finally, the third problem is that both approaches only address endogeneity caused by unobserved time-invariant influences but not endogeneity due to unobserved time-varying factors. Or put differently, the introduction or abolishment of a council may still suffer from endogeneity. ${ }^{10}$ Propensity score matching cannot overcome this limitation as it is based on the selection on observables assumption (Angrist, 1998).

Against this background, we pursue an alternative approach and estimate a treatment-effects model (Jirjahn, 2010; Mueller, 2012). First, a probit model is used to estimate the determinants of works council incidence. From this estimation the inverse Mills ratio is calculated for each observation. The inverse Mills ratio is included in the productivity regression along with other explanatory variables. Standard errors are adjusted accordingly. In principle, the model is identified by its inherent nonlinearity. However, to avoid that identification is only ensured by distributional assumption, an exclusion restriction is usually imposed. Finding a convincing exclusion restriction is always a matter of debate so that also the treatment-effects regression can be viewed as largely exploratory. Here we use the share of establishments with a works council within 25 narrowly defined industrial groups of the trade, the service and the manufacturing sector. The share of establishments with a council reflects workers' general taste for representation within an industry. Hence, it should have a positive influence on the individual establishment's probability of having a council. However, there is no reason to anticipate that the share of establishments with a council should directly influence the individual establishment's productivity. Researchers have applied similar aggregation identification strategies in other contexts. Machin and Wadhwani (1991) use the unionization rate within industries to instrument unionization at the establishment level. Lee (2004) uses the share of government jobs in a locality to instrument public sector employment by workers. Woessmann and West (2006) use average class size within schools as an instrument for actual class size. Finally, Cornelissen et al. (2011) use the share of workers receiving performance pay within industries to instrument the individual worker's chance of receiving performance pay.

Table A2 provides separate estimates for domestic- and foreign-owned establishments. For a matter of comparison, columns (1) and (4) show the results of OLS regressions. These results confirm that the role of works councils sharply differs between both types of establishments. The works council variable takes a positive coefficient in the estimates with domestic-owned establishments and a negative coefficient in the estimates with foreign-owned establishments (even though the negative coefficient is only statistically significant in the estimations with all foreign-owned establishments). Columns (2) and (5) present the probit estimates. The share of establishments with a works council is a highly significant determinant

${ }^{10}$ In that case, a change in the works council status is no natural but an unnatural experiment (see Besley and Case, 2000). 
of the individual establishment's probability of having a works council. This holds true for both domestic- and foreign-owned establishments.

Columns (3) and (6) provide the productivity regressions which include the inverse Mills ratio. The coefficient on the inverse Mills ratio is significantly negative in the estimates for domestic-owned establishments. This indicates endogeneity of works councils for this type of establishments. The negative coefficient on the inverse Mills ratio implies that the error terms in the probit and the productivity regression are negatively correlated. Thus, OLS underestimates the productivity-enhancing effect of works councils in domestic-owned establishments. By contrast, the inverse Mills ratio is insignificant in the estimates with foreign-owned establishments. Hence, there is no evidence of endogeneity for this type of establishments. Including the inverse Mills ratio renders the negative coefficient on works council incidence in the estimation with all foreign-owned establishments statistically insignificant. This might suggest that works councils play, at best, no role in foreign-owned establishments. Yet, the insignificance of the negative coefficient is due to an increased standard error and not due to a change in the magnitude of the coefficient. Moreover, there is no need to include the inverse Mills ratio in the estimation for foreign-owned establishments as it proves to be insignificant in that estimation. Hence, for foreign-owned establishments, the regression without the inverse Mills ratio is preferred. That regression suggests a negative role of works councils.

Altogether, even when taking the potential endogeneity of works councils into account, the estimates confirm the basic pattern of results. A productivityenhancing role of works councils holds true for domestic-owned establishments. Works councils appear to play a rather negative role in foreign-owned establishments.

\section{Conclusions}

From a theoretical viewpoint the interplay between foreign owners and codetermination is not clear. On the one hand, works councils may reduce the high degree of uncertainty and ambiguity existing in foreign-owned establishments. This may foster workers' effort and cooperation. On the other hand, limited access to information possessed by the foreign parent company's managers, reduced power of the council to protect workers' interests, and a possibly stronger focus of foreign owners on short-term shareholder value may result in adversarial industrial relations and delayed decisions. Using the IAB Establishment Panel, our analysis provides evidence of a negative interaction. In domestic-owned establishments, works councils are associated with higher establishment performance. In contrast, they are negatively associated with establishment performance in foreignowned establishments. This supports the view that foreign direct investment is a challenge for the industrial relations in Germany.

We recognize the need for continued research within this theme. First, future research may analyse the dynamics of the interaction between foreign ownership 
and works councils. It would be interesting to examine whether or not the negative interaction effect diminishes as foreign owners and works councils accumulate experience with each other. Second, future work could examine whether the negative interaction effect depends on the home country of the foreign owner. US multinationals might be less willing to adapt to the local institution of German works councils than European multinationals which may have their own versions of works councils.

\section{Funding}

Hans Boeckler Foundation (S-2007-76-2 F to U.J.).

\section{References}

Adams, R. (1985) Should works councils be used as industrial relations policy? Monthly Labor Review, 108, 25-9.

Addison, J., Bellmann, L., Schnabel, C., and Wagner, J. (2003) German works councils old and new: incidence, coverage and determinants, Schmollers Jahrbuch, 123, 339-58.

Addison, J., Bellmann, L., Schnabel, C., and Wagner, J. (2004) The reform of the German Works Constitution Act: a critical assessment, Industrial Relations, 43, 392-420.

Addison, J., Schank, T., Schnabel, C., and Wagner, J. (2006) German works councils in the production process, Schmollers Jahrbuch, 126, 251-83.

Addison, J., Schnabel, C., and Wagner, J. (2001) Works councils in Germany: their effects on establishment performance, Oxford Economic Papers, 53, 659-94.

Addison, J., Siebert, W., Wagner, J., and Wei, X. (2000) Worker participation and firm performance: evidence from Germany and Britain, British Journal of Industrial Relations, 38, $7-48$.

Agell, J. (1999) On the benefits from rigid labour markets: norms, market failures and social insurance, Economic Journal, 100, 143-64.

Andrews, M., Bellmann, L., Schank, T., and Upward, R. (2007) Foreign-owned plants and job security, Research Paper 2007/36, Leverhulme Centre for Research on Globalization and Economic Policy, University of Nottingham.

Andrews, M., Bellmann, L., Schank, T., and Upward, R. (2009) The takeover and selection effects of foreign-owned establishments: an analysis using linked employer-employee data, Review of World Economics, 145, 295-317.

Angrist, J. (1998) Estimating the labor market impact of voluntary military service using social security data on military applicants, Econometrica, 66, 249-88.

Askildsen, J., Jirjahn, U., and Smith, S. (2006) Works councils and environmental investment: theory and evidence from German panel data, Journal of Economic Behavior and Organization, 60, 346-72.

Bellak, C. (2004) How domestic and foreign firms differ and why does it matter? Journal of Economic Surveys, 18, 483-514.

Bernard, A. and Sjoeholm, F. (2003) Foreign owners and plant survival, NBER Working Paper No. 10039, Cambridge, MA. 
Besley, T. and Case, A. (2000) Unnatural experiments? Estimating the incidence of endogenous policies, Economic Journal, 110, F672-94.

Bloom, N. and Van Reenen, J. (2010) Why do management practices differ across firms and countries? Journal of Economic Perspectives, 24, 203-24.

Bognanno, M., Keane, M., and Yang, D. (2005) The influence of wages and industrial relations environments on the production location decisions of US multinational corporations, Industrial and Labor Relations Review, 58, 171-200.

Bryson, A. (2004) Unions and workplace closure in Britain, 1990-1998, British Journal of Industrial Relations, 42, 283-302.

Budd, J. and Slaughter, M. (2004) Are profits shared across borders? Evidence on international rent sharing, Journal of Labor Economics, 22, 525-52.

Caves, R. (1996) Multinational Enterprises and Economic Analysis, 2nd edition, Cambridge University Press, Cambridge.

Cooke, W. (1997) The influence of industrial relations factors on US foreign direct investment abroad, Industrial and Labor Relations Review, 51, 3-17.

Cooke, W. (2001) Union avoidance and foreign direct investment in the USA, Employee Relations, 6, 558-80.

Cornelissen, T., Heywood, J., and Jirjahn, U. (2011) Performance pay, risk attitudes and job satisfaction, Labour Economics, 18, 229-39.

Dreher, A. and Gaston, N. (2007) Has globalisation really had no effect on unions? Kyklos, 60, 165-86.

Doeringer, P., Evans-Klock, C., and Terkla, D. (1998) Hybrids or hodgepodges? Workplace practices of Japanese and domestic startups in the United States, Industrial and Labor Relations Review, 51, 171-86.

Doucouliagos, C. and Laroche, P. (2003) What do unions do to productivity? Industrial Relations, 42, 650-91.

Fabbri, F., Haskel, J., and Slaughter, M. (2003) Does nationality of ownership matter for labor demands? Journal of the European Economic Association, 1, 698-707.

Fernie, S. and Metcalf, D. (1995) Participation, contingent pay, representation and workplace performance: evidence from Great Britain, British Journal of Industrial Relations, 33, 379-415.

Freeman, R., Kruse, D., and Blasi, J. (2008) The same yet different: worker reports on labour practices and outcomes in a single firm across countries, Labour Economics, 15, 750-71.

Freeman, R. and Lazear, E. (1995) An economic analysis of works councils, in J. Rogers and W. Streeck (eds) Works Councils - Consultation, Representation and Cooperation in Industrial Relations, University of Chicago Press, Chicago, IL, 27-52.

Freeman, R. and Rogers, J. (1999) What Workers Want, Cornell University Press, Ithaca, NY.

Frege, C. (2002) A critical assessment of the theoretical and empirical research on German works councils, British Journal of Industrial Relations, 40, 221-48.

Frick, B. (2002) Ökonomische Analyse der deutschen Betriebsverfassung, in D. Sadowski and U. Walwei (eds) Die ökonomische Analyse des Arbeitsrechts, Bundesanstalt für Arbeit, Nürnberg. 
Frick, B. and Moeller, I. (2003) Mandated works councils and firm performance: labor productivity and personnel turnover in German establishments, Schmollers Jahrbuch, 123, 423-54.

Gaston, N. (2002) The effects of globalisation on unions and the nature of collective bargaining, Journal of Economic Integration, 17, 377-96.

Girma, S. and Goerg, H. (2004) Outsourcing, foreign ownership, and productivity: evidence from UK establishment-level data, Review of International Economics, 12, 817-32.

Goerg, H. and Strobl, E. (2003) Footloose multinationals? Manchester School, 71, 1-19.

Hall, P. and Soskice, D. (2001) Varieties of Capitalism: The Institutional Foundations of Comparative Advantage, Oxford University Press, Oxford.

Hamm, H. and Kleiner, M. (2007) Do industrial relations institutions influence foreign direct investment? Evidence from OECD nations, Industrial Relations, 46, 305-28.

Heywood, J. and Jirjahn, U. (2002) Payment schemes and gender in Germany, Industrial and Labor Relations Review, 56, 44-64.

Heywood, J. and Jirjahn, U. (2009) Family friendly practices and worker representation: German evidence, Industrial Relations, 48, 121-45.

Heywood, J., Jirjahn, U., and Tsertsvadze, G. (2010) Hiring older workers and employing older workers: German evidence, Journal of Population Economics, 23, 595-615.

Hijzen, A., Martins, P., Schank, T., and Upward, R. (2010) Do foreign-owned firms provide better working conditions than their domestic counterparts? A comparative analysis, IZA Discussion Paper 5259, Bonn.

Huebler, O. and Jirjahn, U. (2003) Works councils and collective bargaining in Germany: the impact on productivity and wages, Scottish Journal of Political Economy, 50, 1-21.

Jackson, G., Hoepner, M., and Kurdelbusch, A. (2005) Corporate governance and employees in Germany: changing linkages, complementarities and tensions, in H. Gospel and A. Pendleton (eds) Corporate Governance and Labour Management: an International Comparison, Oxford University Press, Oxford, 84-121.

Jirjahn, U. (2003a) Executive incentives, works councils and firm performance, Schmollers Jahrbuch, 123, 397-421.

Jirjahn, U. (2003b) Produktivitätswirkungen betrieblicher Mitbestimmung - Welchen Einfluss haben Betriebsgröße und Tarifbindung? Zeitschrift für Betriebswirtschaft, 73, 63-85.

Jirjahn, U. (2009) The introduction of works councils in German establishments - rent seeking or rent protection? British Journal of Industrial Relations, 47, 521-45.

Jirjahn, U. (2010) Works councils and employment growth in German establishments, Cambridge Journal of Economics, 34, 475-500.

Jirjahn, U. and Kraft, K. (2007) Intra-firm wage dispersion and firm performance - is there a uniform relationship? Kyklos, 60, 231-53.

Jirjahn, U. and Kraft, K. (2011) Do spillovers stimulate incremental or drastic product innovations? Evidence from German establishment data, Oxford Bulletin of Economics and Statistics, 73, 509-38.

Jirjahn, U., Mohrenweiser, J., and Backes-Gellner, U. (2011) Works councils and learning: on the dynamic dimension of codetermination, Kyklos, 64, 427-47. 
Jirjahn, U. and Smith, S. (2006) What factors lead management to support or oppose employee participation - with and without works councils? Hypotheses and evidence from Germany, Industrial Relations, 45, 650-80.

Kleiner, M. and Lee, Y. (1997) Works councils and unionization: lessons from South Korea, Industrial Relations, 36, 1-16.

Kostova, T. and Roth, K. (2002) Adoption of an organizational practice by subsidiaries of multinational corporations: institutional and relational effects, Academy of Management Journal, 45, 215-33.

Lee, S. (2004) A re-examination of public sector wage differentials in the United States: evidence from the NLSY with Geocode, Industrial Relations, 43, 448-72.

Lindbeck, A. and Snower, D. (2001) Centralized bargaining and reorganized work: are they compatible? European Economic Review, 45, 1851-75.

Machin, S. and Wadhwani, S. (1991) The effects of unions on organizational change and employment, Economic Journal, 101, 835-54.

Markusen, J. (1995) The boundaries of multinational enterprises and the theory of international trade, Journal of Economic Perspectives, 9, 169-89.

Mohrenweiser, J., Marginson, P., and Backes-Gellner, U. (2012) What triggers the establishment of a works council? Economic and Industrial Democracy, 33, 295-316.

Mueller, M. (1998) Human resource and industrial relations practices of UK and US multinationals in Germany, International Journal of Human Resource Management, 9, 732-49.

Mueller, S. (2008) Capital stock approximation using firm level panel data, Jahrbücher für Nationalökonomie und Statistik, 228, 357-71.

Mueller, S. (2011) Works councils and firm profits revisited, British Journal of Industrial Relations, 49, s27-43.

Mueller, S. (2012) Works councils and establishment productivity, Industrial and Labor Relations Review, 65, 880-898.

Navaretti, G., Checchi, D., and Turrini, A. (2003) Adjusting labor demand: multinational versus national firms: a cross-European analysis, Journal of the European Economic Association, 1, 708-19.

Pfeifer, C. (2011) Works councils, union bargaining, and quits in German firms, Economic and Industrial Democracy, 32, 243-60.

Poutsma, E., Ligthart, P., and Veersma, U. (2006) The diffusion of calculative and collaborative HRM practices in European firms, Industrial Relations, 45, 513-46.

Raess, D. and Burgoon, B. (2006) The dogs that sometimes bark: globalization and works council bargaining in Germany, European Journal of Industrial Relations, 12, 287-309.

Renaud, S. (2008) Arbeitnehmermitbestimmung im Strukturwandel, Metropolis, Marburg.

Royle, T. (1998) Avoidance strategies and the German system of co-determination, International Journal of Human Resource Management, 9, 1026-47.

Scheve, K. and Slaughter, M. (2004) Economic insecurity and the globalization of production, American Journal of Political Science, 48, 662-74.

Schmitt, M. (2003) Deregulation of the German industrial relations system via foreign direct investment: are the subsidiaries of Anglo-Saxon MNCs a threat for the institutions of industrial democracy in Germany? Economic and Industrial Democracy, 24, 349-77. 
Shleifer, A. and Summers, L. (1988) Breach of trust in hostile takeovers, in A. Auerbach (ed.) Corporate Takeovers: Causes and Consequences, University of Chicago Press, Chicago, IL, 33-68.

Slaughter, M. (2007) Globalization and declining unionization in the United States, Industrial Relations, 46, 329-46.

Smith, S. (2006) Employee participation rights in corporate governance: economic rationale, a test of a leading theory, and some modest policy proposals, Advances in the Economic Analysis of Participatory and Labor Managed Firms, 9, 105-46.

Smith, S. (1991) On the economic rationale for codetermination law, Journal of Economic Behavior and Organization, 12, 261-81.

UNCTAD (2004) World Investment Report 2004, United Nations, New York.

Wagner, J. (2008) German works councils and productivity: first evidence from a nonparametric test, Applied Economics Letters, 15, 727-30.

Wagner, J., Schank, T., Schnabel, C., and Addison, J. (2006) Works councils, labor productivity and plant heterogeneity: first evidence from quantile regressions, Jahrbücher für Nationalökonomie und Statistik, 226, 505-18.

Walsh, J. (2001) Human resource management in foreign-owned workplaces: evidence from Australia, International Journal of Human Resource Management, 12, 425-44.

Woessmann, L. and West, M. (2006) Class-size effects in school systems around the world: evidence from between-grade variation in TIMMS, European Economic Review, 50, 695-736. 


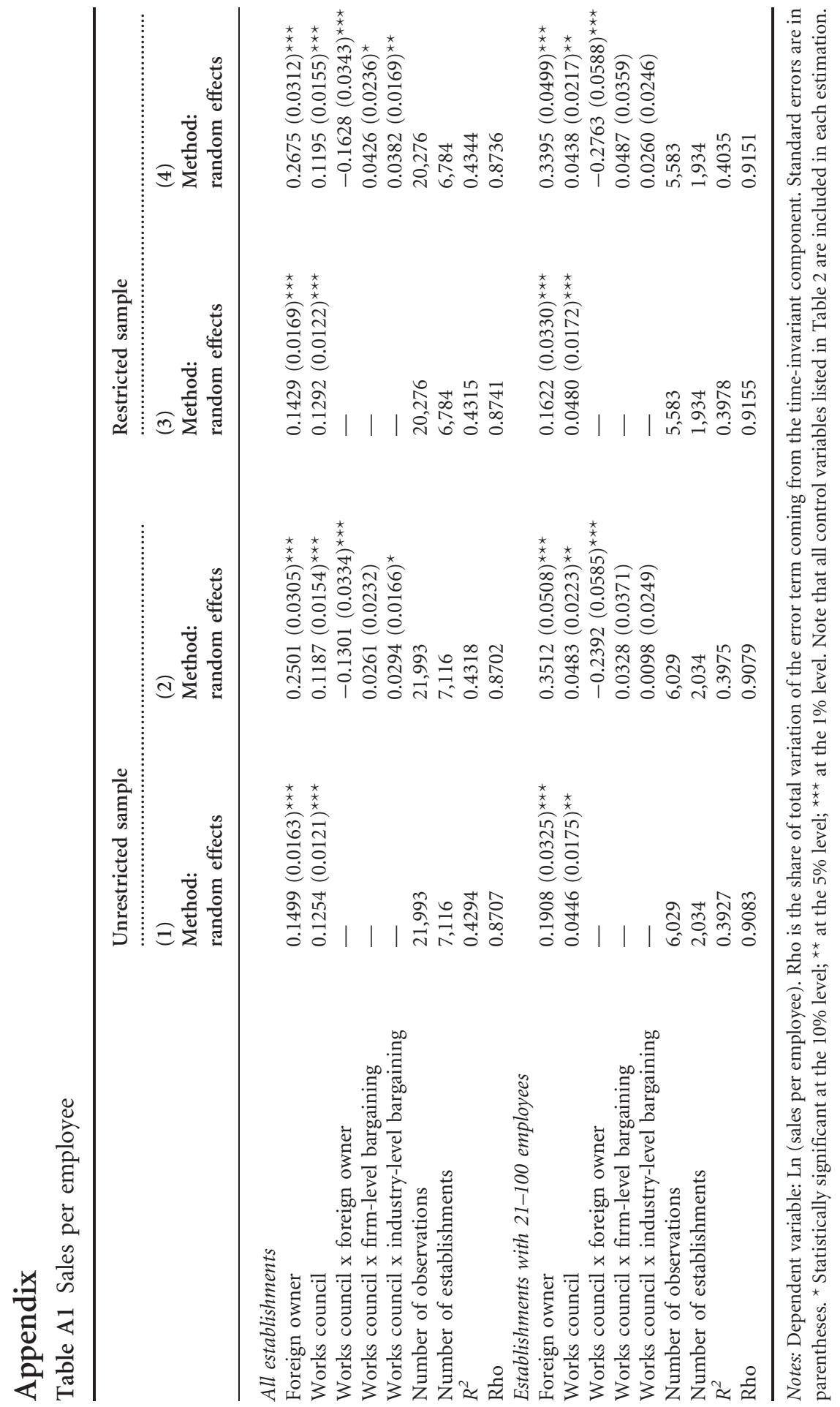

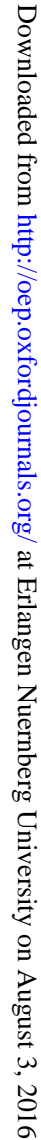




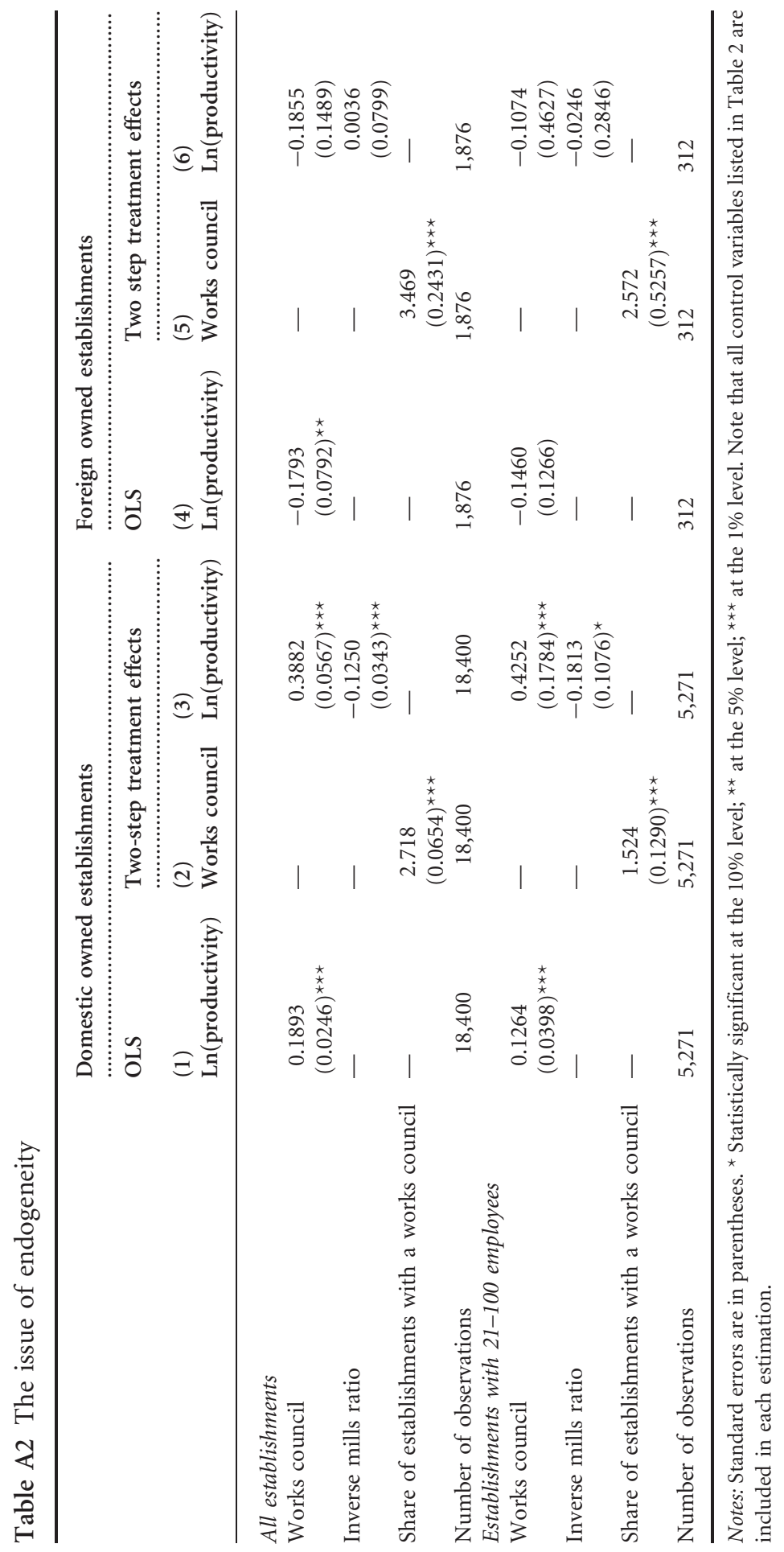

